\title{
Efektivitas Berbagai Media Pasir Lokal Sebagai Media Filtrasi Air Baku Menjadi Air Untuk Kebutuhan Higiene Sanitasi
}

\author{
The Effectiveness Of Various Local Sand Media As Filtration Media Raw Water To \\ Water For Needs Hygiene Sanitation
}

\author{
Tony K. Timpua ${ }^{\text {a }}$ Agnes T. Watung ${ }^{\mathrm{a}}$ \\ Jurusan Kesehatan Lingkungan Poltekkes Kemenkes Manado, Indonesia
}

\section{A B S T R A C T / A B S T R A K}

\begin{abstract}
Meeting the needs of clean water services in the community requires innovation with appropriate technology by developing groundwater or well water treatment (filtering) which has a high turbidity level so that clean water is obtained with quality that meets health requirements The water processing (filtering) is the Water Well Submerged Filter by using filter media, namely sand, gravel, activated carbon, and fibers. The purpose of this study was to determine the ability of the immersed water filter to reduce water turbidity, $\mathrm{Fe}$, Mn content and total coliform. This type of research is experimental with the design of One Group Pretest-Posttest Design.

The results showed that the immersed water filter was effective in reducing turbidity and Fe content in the water, while the immersion filter's ability to reduce the Mn content and total coliform was not effective. It was concluded that the Up Flow Sand Filter in which A filter with sea sand media, $B$ filter with land sand medium and $C$ filter with sea sand media effectively reduced the turbidity and manganese levels, while the total coliform for and E. coli still exceeded the required quality standards. Further research needs to be done on the effect of varying media thickness and finer diameter in order to reduce colform and E. coli effectively
\end{abstract}

Key words: Media, sand, turbidity, Fe, Mn, Coliform, E. coli

\begin{abstract}
Pemenuhan kebutuhan layanan air bersih pada masyarakat perlu inovasi dengan teknologi tepat guna dengan cara pengembangan pengolahan (penyaringan) air tanah atau air sumur yang mempunyai tingkat kekeruhan tinggi sehingga didapatkan air bersih dengan kualitas yang memenuhi syarat kesehatan. Pengolahan (penyaringan) air dimaksud adalah Saringan Air Celup Sumur Gali dengan menggunakan media saring yaitu pasir, kerikil, karbonaktif, dan ijuk. Tujuan penelitian ini adalah untuk mengetahui kemampuan saringan air celup untuk menurunkan kekeruhan air, kandungan Fe, Mn dan total coliform. Jenis Penelitian ini eksperimen dengan rancarangan One Group Pretest-Posttest Design.

Hasil penelitian menunjukkan saringan air celup efektif menurunkan kekeruhan dan kadar $\mathrm{Fe}$ dalam air sedangkan kemampuan saringan celup untuk menurukan kadar Mn dan total coliform tidak efektif. Disimpulkan bahwa Saringan Pasir Up Flow dimana saringan A dengan media pasir laut, saringan B dengan media pasir darat dan saringan $\mathrm{C}$ dengan media pasir laut efektif menurunkan kadar kekeruhan dan mangan, sedangkan total coliform untuk dan E.coli masih melebihi baku mutu yg disyaratkan. Perlu dilakukan penelitian lanjutan terhadap pengaruh ketebalan media yang bervariasi dan diameter yang lebih halus agar dapat menurunkan colform dan E.coli secara efektif
\end{abstract}

Kata kunci: Media, Pasir, kekeruhan, Fe, Mn, Coliform, E.coli 


\section{Pendahuluan}

Menurut Kurniawan (2015), bahwa salah satu kendala utama dalam penyediaan air bersih di Indonesia adalah terbatasnya pasokan air. Sebagian besar PDAM beroperasi dengan mengandalkan air baku dari air sungai yang terus mengalami penurunan debit. Sungai Bengawan Solo turun hingga 44,18 $\mathrm{m}^{3} / \mathrm{det}$, Sungai Serayu turun hingga 45,76 $\mathrm{m}^{3} / \mathrm{det}$, dan Sungai Cisadane turun hingga $45,10 \mathrm{~m}^{3} /$ det.

Salah satu sumber air alternatif untuk memenuhi kebutuhan air bersih masyakarat baik di daerah pedesaan maupun di perkotaan adalah sumur gali, tetapi kualitas air sumur gali juga masih rendah. Profil Kesehatan Kota Manado tahun 2012 terdapat 11,8\% masyarakat Kota Manado menggunakan sumur gali sebagai sumber air bersih yang digunakan untuk keperluan rumah tangga dan keperluan air minum (Tombokan, 2014). Katiho, dkk (2011), mengemukakan bahwa kondisi fisik (konstruksi) sumur gali tidak memenuhi syarat. Harmayani, dkk. (2007), bahwa tingkat kekeruhan air sumur gali ratarata $87,5 \mathrm{mg} \mathrm{SiO} 2 / 1$, kandungan bakteri E.coli rata-rata $6,8 / 100 \mathrm{ml}$ dan Coliform rata-rata $518 / 100 \mathrm{ml}$. Untuk mengatasi permasalahan tersebut diperlukan filtrasi untuk menyempurnakan penurunan kadar kontaminan seperti bakteri, warna, rasa, bau dan $\mathrm{Fe}$ sehingga diperoleh air yang bersih yang memenuhi standar.

Menurut Suprihatin, dkk (2013) Filtrasi termasuk dalam golongan proses secara mekanis atau fisik. Efek utama filtrasi adalah penahanan partikel-partikel yang memiliki ukuran lebih besar dari ukuran pori

filter. Pengendapan/penempelan partikel pada butiran media filter terjadi akibat mekanisme daya van der Waal, daya elektrokimia (adsorpsi), reaksi kimia, dan reaksi biologis.

Proses penyaringan air yang sudah banyak dikenal di masyarakat adalah saringan pasir lambat (slow sand filter) dan saringan pasir cepat (rapid sand filater). Menurut Chandra (2007), Saringan air celup sumur gali untuk menurunkan kekeruhan air adalah suatu unit pengolahan air yang terbuat dari rangkaian pipa paralon (PVC) dengan menggunakan media saring pasir, kerikil, arang batok kelapa dan ijuk yang dapat ditempatkan langsung di dalam sumur gali. Saringan air celup ini adalah pengembangan dari hasil penelitian uji coba saringan air celup dengan media pasir, kerikil, arang, dan ijuk untuk menurunkan kekeruhan air yang dirancang oleh Tombokan (2014) dan dikembangkan oleh Timpua, dkk (2015) saringan air celup terbukti mampu menurunkan tingkat kekeruhan air dengan rata-rata persentase penurunan sebesar $85,82 \%$.

\section{Metode}

Penelitian ini termasuk dalam penelitian eksperimen (Pre experimental Design) dengan rancarangan One Group Pretest-Posttest Design, pada rancangan ini, kelompok penelitian dilakukan pengukuran sebelum perlakuan (pre test) dan pengukuran sesudah perlakuan (post test) sehingga hasil perlakuan dapat diketahui lebih akurat karena dapat membandingkan hasil sebelum dan sesudah perlakuan (Sugiyono, 2012). 


\section{Hasil}

\section{Desain/Rancanga Alat}

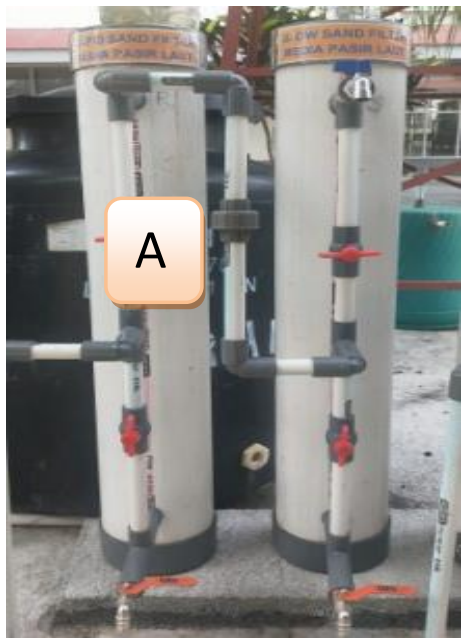

SPC-SPL MEDIA PASIR LAUT KETEBALAN MEDIA $60 \mathrm{CM}$ DIAMETER PIPA PVC 6 INCHI

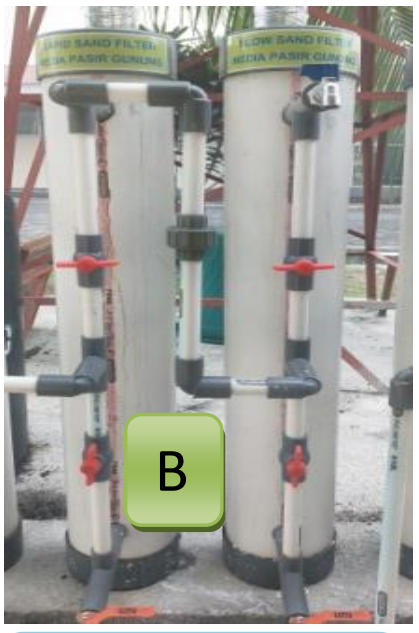

SPC-SPL MEDIA PASIR GUNUNG KETEBALAN MEDIA 60 CM DIAMETER PIPA PVC 6 INCHI

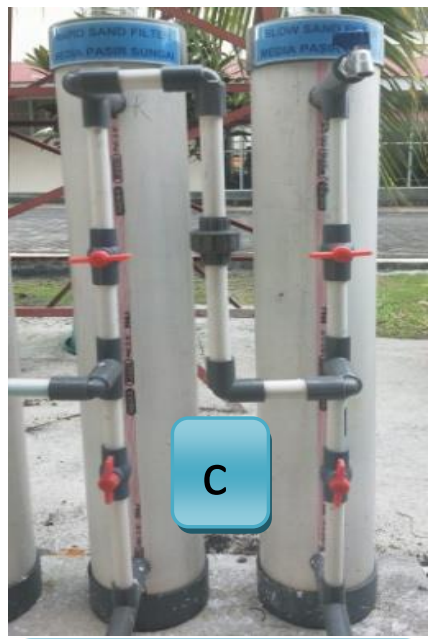

SPC-SPL MEDIA PASIR SUNGAI KETEBALAN MEDIA 60 CM DIAMETER PIPA PVC $6 \mathrm{INCHI}$

Gambar 1: Desain Dan Spesifikasi Alat

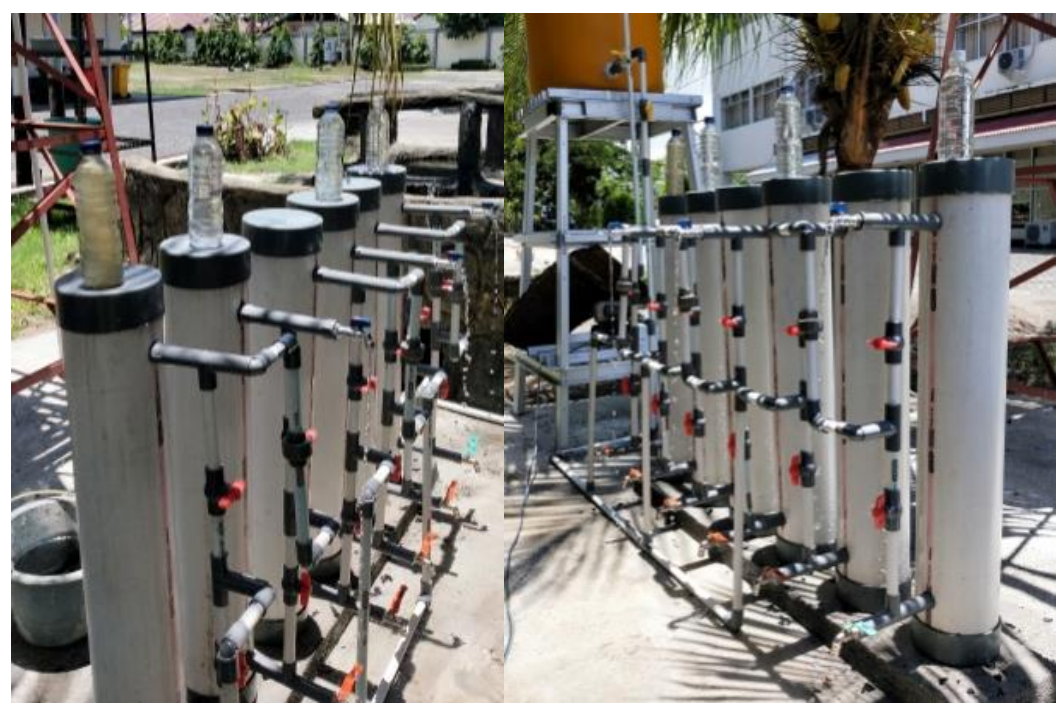

Gambar 2. Rangkaian Alat

\section{Deskripsi Alat:}

Desain alat saringan ini dirancang sedemikian rupa menggunakan bahan lokal, sehingga mudah dalam pembuatan dan pengoperasiannya. Saringan ini terbuat dari pipa PVC diameter 6 inchi $(\mathrm{D}=15 \mathrm{~cm})$, menggunakan tiga jenis media pasir yaitu saringan A menggunakan media pasir laut/pasir pantai, saringan B menggunakan media pasir pasir darat/gunung dan saringan $\mathrm{C}$ menggunakan media pasir pasir sungai, dengan ketebalan media masing-masing 60 $\mathrm{cm}$. Sistem aliran saringan ini diatur dari bawah ke atas (up flow), untuk menghindari penumpukan material organik dalam air baku, sehingga dapat menyumbat media saringan. 


\section{Hasil}

Hasil penelitian dan pengolahan data, dapat diuraikan sebagai berikut :

Tabel 1. Rerata Kadar Kekeruhan Sebelum dan Sesudah Filtrasi Air Baku Menurut Jenis Media Saringan

\begin{tabular}{cccccc}
\hline \multirow{2}{*}{ No } & \multirow{2}{*}{ Saringan } & \multicolumn{2}{c}{ Hasil pengukuran } & Selisih & Penurunan \\
& & Sebelum & Sesudah & Kekeruhan & $(\%)$ \\
\hline 1 & A & 9,80 & 0,94 & 8,86 & 90,44 \\
2 & B & 9,80 & 1,00 & 8,80 & 89,80 \\
3 & C & 9,80 & 0,93 & 8,87 & 90,48 \\
\hline
\end{tabular}

Tabet 1 menunjukkan rerata kekeruhan air sebelum dan sesudah penyaringan sedikit bervariasi menurut jenis media saringan pasir up flow. Secara keseluruhan ketiga saringan memiliki kemampuan menyaring yang efektif menurunkan kekeruhan. Penurunan tertinggi terjadi pada saringan $\mathrm{C}$ dengan mendia pasir sungai

$(90,48 \%)$.

Tabel 2. Rerata Kadar Besi (Fe) Sebelum dan Sesudah Filtrasi Air Baku Menurut Jenis Media Saringan Up Flow

\begin{tabular}{|c|c|c|c|c|c|}
\hline \multirow{2}{*}{ No } & \multirow{2}{*}{ Saringan } & \multicolumn{2}{|c|}{ Hasil pengukuran } & \multirow{2}{*}{$\begin{array}{c}\text { Selisih } \\
\text { Besi (fe) }\end{array}$} & \multirow{2}{*}{$\begin{array}{c}\text { Penurunan } \\
(\%)\end{array}$} \\
\hline & & Sebelum & Sesudah & & \\
\hline 1 & A & 0,02 & 0,0025 & 0,0175 & 87,5 \\
\hline 2 & $\mathrm{~B}$ & 0,02 & 0,0025 & 0,0175 & 87,5 \\
\hline 3 & $\mathrm{C}$ & 0,02 & 0,0025 & 0,0175 & 87,5 \\
\hline
\end{tabular}

Pada Tabel 2 terlihat baik saringan A, B, dan C mempunyai kemampuan menurunkan kadar Fe secara efektif $(87,5 \%)$.

Tabel 3. Rerata Kadar Besi (Fe) Sebelum dan Sesudah Filtrasi Air Baku Menurut Jenis Media Saringan Up Flow

\begin{tabular}{cccccc}
\hline \multirow{2}{*}{ No } & \multirow{2}{*}{ Saringan } & \multicolumn{2}{c}{ Hasil pengukuran } & \multicolumn{2}{c}{$\begin{array}{c}\text { Selisih } \\
\text { Mangan }(\mathrm{mn})\end{array}$} \\
& & Sebelum & Sesudah & Penurunan \\
& A & 4,04 & 0,31 & 3,73 & 96,35 \\
2 & B & 4,04 & 0,49 & 3,55 & 86,96 \\
3 & C & 4,04 & 0,42 & 3,62 & 87,64 \\
\hline
\end{tabular}

Tabet 3 menunjukkan rerata kadar Mangan (Mn) sebelum dan sesudah penyaringan bervariasi menurut jenis media saringan pasir up flow. Secara keseluruhan ketiga saringan memiliki kemampuan menyaring yang efektif menurunkan kadar Mangan. Penurunan tertinggi terjadi pada saringan A dengan mendia pasir laut $(96,35 \%)$. 
Tabel 4. Rerata MPN Coliform Total Sebelum dan Sesudah Filtrasi Air Baku Menurut Jenis Media Saringan Up Flow

\begin{tabular}{cccccc}
\hline \multirow{2}{*}{ No } & \multirow{2}{*}{ Saringan } & \multicolumn{2}{c}{ Hasil pengukuran } & \multicolumn{2}{c}{$\begin{array}{c}\text { Selisih } \\
\text { Total coliform }\end{array}$} \\
& & Sebelum & Sesudah & Penurunan \\
& A & 1966,67 & 92,07 & 1874,6 & 94,19 \\
2 & B & 2400 & 56,33 & 2343,67 & 97,65 \\
3 & C & 2400 & 56,33 & 2343,67 & 97,65 \\
\hline
\end{tabular}

Tabet 4 menunjukkan rerata MPN Coliform sebelum dan sesudah penyaringan bervariasi menurut jenis media saringan pasir up flow. Secara keseluruhan ketiga saringan memiliki kemampuan menyaring dan dapat menurunkan MPN Coliform. Penurunan tertinggi terjadi pada saringan $\mathrm{B}$ dengan media pasir gunung dan saringan $\mathrm{C}$ dengan mendia pasir sungai $(97,65 \%)$.

Tabel 5. Rerata MPN E.Coli Sebelum dan Sesudah Filtrasi Air Baku Menurut Jenis Media Saringan Up Flow

\begin{tabular}{cccccc}
\hline \multirow{2}{*}{ No } & \multirow{2}{*}{ Saringan } & \multicolumn{2}{c}{ Hasil pengukuran } & Selisih E.coli & Penurunan (\%) \\
& & Sebelum & Sesudah & & \\
\hline 1 & A & 1966,67 & 140 & 1826,67 & 92,2 \\
2 & B & 1966,67 & 166,33 & 1800,33 & 85,52 \\
3 & C & 1966,67 & 18,67 & 1848 & 99,07 \\
\hline
\end{tabular}

Tabet 5 menunjukkan rerata MPN E.Cli sebelum dan sesudah penyaringan bervariasi menurut jenis media saringan pasir up flow. Secara keseluruhan ketiga saringan memiliki kemampuan menyaring yang efektif menurunkan kadar Mangan. Penurunan tertinggi terjadi pada saringan $\mathrm{C}$ dengan mendia pasir laut $(99,07 \%)$.

\section{Pembahasan}

\section{Kekeruhan}

Kekeruhan adalah efek optik yang terjadi jika sinar membentuk material tersuspensi di dalam air. Kekeruhan air dapat ditimbulkan oleh adanya bahan-bahan organik dan anorganik seperti pelapukan, lumpur dan buangan, dari permukaan tertentu yang menyebabkan air baku menjadi keruh. Kekeruhan dapat menyebabkan warna air menjadi warna yang lebih tua dari warna air sesungguhnya.

Hasil penelitian pada Tabel 1, menunjukkan kadar kekeruhan sesudah Filtrasi telah memenuhi syarat untuk keperluan hygiene sanitasi sesuai permenkes 32 tahun 2017 dengan persentase penurunan tertinggi pada saringan C yakni 90,48\%, memenuhi kriteria obyektif dikatakan efektif jika Saringan celup dapat menurunkan kekeruhan lebih dari $80 \%$.

Hasil penelitian sebelumnya oleh Timpua, dkk (2015) tentang modifikasi saringan celup sumur gali untuk menurunkan kekeruhan menunjukkan efektivitas penurunan kekeruhan mencapai 92,59\%. Persentase penurunan tingkat kekeruhannya lebih tinggi disebabkan diameter pasir yang digunakan lebih kecil, yaitu $1 \mathrm{~mm}$ dan suspensi akan terpisah dengan air karena suspensi tidak dapat melewati pori-pori dari media penyaring yang digunakan sehingga mengakibatkan nilai turbiditas berkurang dimana nilai turbiditas bertambah seiring dengan banyaknya partikel atau suspensi yang terdapat di dalam air.

Air yang mengandung kekeruhan tinggi akan mengalami kesulitan bila diproses untuk sumber air bersih. Kesulitannya antara lain dalam proses 
penyaringan. Hal lain yang tidak kalah pentingnya adalah bahwa air dengan kekeruhan tinggi akan sulit untuk didesinfeksi, yaitu proses pembunuhan terhadap kandungan mikroba yang tidak diharapkan. Tingkat kekeruhan dipengaruhi oleh $\mathrm{pH}$ air, kekeruhan pada air minum umumnya telah diupayakan sedemikian rupa sehingga air menjadi jernih (Quddus, 2016)

Kekeruhan dalam air baku disebabkan oleh adanya bahan organik terlarut dan karena aktifitas bakteri dalam air dengan satuan Nephelometrik Turbidity Unit (NTU) atau dikenal dengan skala silica $\left(\mathrm{SiO}_{2}\right)$. Kekeruhan sesuai standar kualitas air dalam Peraturan Menteri Kesehatan Nomor: 416/MEN.KES/PER/IX/1990 ditetapkan maksimum 5 NTU untuk air minum dan 25 NTU untuk air bersih.

\section{Besi (Fe)}

Besi adalah unsur alam yang dapat ditemukan pada tanah dan batuan. Unsur besi dan mangan dapat dihubungkan dengan pelapukan batuan dan mineral. Dengan alkalinitas yang rendah, kadar Fe dapat mencapai $10 \mathrm{mg} / \mathrm{l}$ dan biasanya terdapat pada air sumur dalam, danau, reservoir (Kawamura, 2000).

Hasil penelitian menunjukkan penurunan kadar $\mathrm{Fe}$ setelah penyaringan mencapai 87,5\%. Hasil penelitian sebelumnya yang dilakukan oleh Maase (2012), diketahui konsentrasi besi (Fe) dalam air yang di manfaatkan sebagai air bersih sesudah proses penyaringan rata-rata tingkat penurunan kadar besi yaitu pada saringan Multimedia dengan sistem aliran dari atas ke bawah (down flow) 0,2007 (91,15\%) dan dari bawah ke atas (up flow) 0,1189 (93,39\%).

Menurut Alaerts, 1987 dalam Taufan (2016) bahwa pada umumnya besi (Fe) dalam air memiliki sifat:

a. Tergabung dengan zat organik atau zat padat inorganik, seperti tanah liat

b. Tersuspensi sebagai butir koloidal (diameter $<1 \mu \mathrm{m}$ ) atau yang lebih besar seperti $\mathrm{Fe}_{2} \mathrm{O}_{3}, \mathrm{FeO}, \mathrm{Fe}(\mathrm{OH})_{3}$ dan sebagainya.

c. Terlarut sebagai $\mathrm{Fe}^{2+}$ (ferro) atau $\mathrm{Fe}^{3+}$ (ferri).

Penyisihan kadar Fe dalam air bisa lebih tinggi bila filtrasi atau penyaringan air dikombinasikan dengan proses aerasi agar terjadi reaksi antara oksigen dengan Fe sehingga $\mathrm{Fe}$ dalam air akan mengendap yang akan mempermudah proses penyaringan melalui pori-pori media saringan.

3. Mangan (Mn)

Kemampuan saringan air up flow untuk menurunkan kadar Mangan mencapai nilai melebihi kriteria objektif yang telah ditentukan. Berdasarkan hasil uji laboratorium rata-rata kadar mangan sebelum penyaringan pada saringan A dengan media pasir laut adalah $4,04 \mathrm{mg} / \mathrm{l}$ dan setelah penyaringan rata-rata kadar mangan $0,31 \mathrm{mg} / \mathrm{l}$ dengan persentase penurunan 96,35\%. Menurut Said (2016) Zat besi dan mangan di dalam air berada dalam keadaan senyawa dengan zat organik. Untuk menghilangkan zat besi atau mangan dalam air paling sering dengan cara oksidasi dan pemisahan padatan. Mangan lebih sulit dioksidasi daripada besi karena kecepatan oksidasi mangan lebih rendah dibanding oksidasi besi.

Keberadaan mangan (Mn) dalam air ada dalam bentuk tersuspensi dan terlarut. Pada air tawar mengandung satu sampai beberapa ribu microgram mangan per liter bahkan pada air tanah sering mengandung mangan $(\mathrm{Mn})$ terlarut dalam kadar tinggi. Kadar mangan yang tinggi biasanya ditemukan pada daerah industri. Pengurangan kadar mangan yang tinggi perlu dilakukan pada air tanah dan pada beberapa danau dan reservoir yang cenderung memiliki kandungan yang sangat tinggi.

Menurut Kaul and Gautam, 2002 dalam Taufan (2016), adanya mangan pada air minum bisa mempengaruhi kesehatan manusia. Pada konsentrasi melebihi 0,15 
$\mathrm{mg} / \mathrm{l}$ dapat menimbulkan rasa yang tidak enak dan menimbulkan noda pada peralatan pipa serta pakaian. Ketika senyawa mangan melalui proses oksidasi, akan dihasilkan endapan mangan. Bahkan pada konsentrasi 0,02 mg/l, mangan akan membentuk lapisan pada pipa berwarna hitam. Mangan juga dapat menyebabkan gangguan pertumbuhan organism. Konsentrasi mangan yang tinggi menimbulkan masalah bau, rasa, dan kekeruhan pada air distribusi

Menurut Said (2016) Baik hidroksika besi ( $\mathrm{Fe}$ ) maupun hidroksida Mangan (Mn) masih mempunyai kelarutan yang cukup besar, sehingga jika terus dilakukan oksidasi dengan udara atau aerasi akan terjadi reaksi (ion) sebagai berikut:

$$
4 \mathrm{Fe}^{2+}+\mathrm{O}_{2}+10 \mathrm{H}_{2} \mathrm{O} \rightarrow 4 \mathrm{Fe}(\mathrm{OH})_{3}+8 \mathrm{H}^{+}
$$$$
2 \mathrm{Mn}^{2+}+\mathrm{O}_{2}+2 \mathrm{H}_{2} \mathrm{O} \rightarrow 2 \mathrm{MnO}_{2}+4 \mathrm{H}^{+}
$$

Sesuai dengan reaksi tersebut, maka untuk mengoksidasi setiap $1 \mathrm{mg} / \mathrm{l}$ zat besi dibutuhkan $0,14 \mathrm{mg} / \mathrm{l}$ oksigen dan setiap $1 \mathrm{mg} / \mathrm{l}$ mangan dibutuhkan 0,29 $\mathrm{mg} / \mathrm{l}$. Pada $\mathrm{pH}$ rendah, kecepatan reaksi oksidasi besi dengan oksigen (udara) relatih lambat, sehingga untuk mempercepat reaksi dilakukan dengan menaikkan $\mathrm{pH}$ air yang akan diolah.

4. Total coliform

Bakteri coliform adalah golongan bakteri intestinal, yaitu hidup didalam saluran pencernaan manusia. Bakteri coliform adalah bakteri indikator keberadaan bakteri patogenik lain. Lebih tepatnya, bakteri coliformfekal adalah bakteri indikator adanya pencemaran bakteri patogen. Penentuan coliform fekal menjadi indikator pencemaran dikarenakan jumlah koloninya pasti berkorelasi positif dengan keberadaan bakteri patogen. Selain itu, mendeteksi coliform jauh lebih murah, cepat, dan sederhana daripada mendeteksi bakteri patogenik lain. Contoh bakteri coliform adalah, Escherichia coli dan Enterobacter aerogenes. Jadi, coliform adalah indikator kualitas air. Makin sedikit kandungan coliform, artinya, kualitas air semakin baik.

Hasil penelitian menujukkan kandungan total coliform sebelum melalui penyaringan dengan rata-rata 2400/100 ml, sesudah penyaringan rata-rata $56,33 / 100 \mathrm{ml}$ dengan persentase penurunan 97,65 . Hal ini disebabkan karena limit deteksi alat ukur hanya mencapai 2400 MPN sehingga jumlah coliform yang sesunguhny lebih dari 2400, hanya terbaca lebih dari 2400. Penurunan bakteri coliform setelah penyaringan juga dapat disebabkan karena belum terbentuknya lapisan biofilm yang optimum. Selain itu, gradasi media filter yang ukurannya masih cukup besar $(2 \mathrm{~mm})$ dapat mengakibatkan bakteri masih bisa lolos (Ati, 2016).

\section{Escherichia Coli (E.Coli)}

Ditemukannya E. coli dalam air merupakan indikator bahwa air tersebut tercemar oleh tinja manusia. Adanya pencemaran tinja ini dapat dianggap berbahaya karena dalam tinja terdapat bermacam-macam mikroorganisme pathogen seperti vibrio cholera, virus, protozoa, telur cacing, amoeba dan lainnya.

Sampai saat ini E. coli masih dipakai sebagai indikator kualitas air limbah secara bakteriologis. Tingkat pencemaran atau efektivitas pengolahan air limbah secara bakteriologis dilihat dari tinggi rendahnya jumlah $E$. coli yang ada didalam air limbah. Digunakannya bakteri E. coli sebagai indikator pencemaran bakteriologis air limbah karena; 1) mudah diidentifikasi; 2) tidak pathogen; 3) jumlahnya dapat dihitung; 4) jumlahnya dapat dikorelasikan dengan kemungkinan adanya kuman pathogen; 5) lebih tahan hidup dilingkungan yang tidak menguntungkan; dan 6) lingkungan optimum sama dengan bakteri pathogen (Soemirat, 1994).

E.coli akan hidup dengan baik bila air limbah mempunyai $\mathrm{pH} 6-8$, suhu antara $20^{\circ} \mathrm{C}-40^{\circ} \mathrm{C}$, dan cukup tersedia nutrisi. Hasil penelitian menujukkan 
kandungan E.coli sebelum melalui penyaringan dengan rata-rata $2400 / 100 \mathrm{ml}$, sesudah penyaringan rata-rata $56,33 / 100 \mathrm{ml}$ dengan persentase penurunan 97,65 . Hal ini disebabkan karena limit deteksi alat ukur hanya mencapai 2400 MPN sehingga jumlah coliform yang sesunguhny lebih dari 2400, hanya terbaca lebih dari 2400 . Penurunan bakteri coliform setelah penyaringan juga dapat disebabkan karena belum terbentuknya lapisan biofilm yang optimum. Selain itu, gradasi media filter yang ukurannya masih cukup besar ( $2 \mathrm{~mm}$ ) dapat mengakibatkan bakteri masih bisa lolos (Ati, 2016).

Tabet 5 menunjukkan rerata MPN E.coli sebelum dan sesudah penyaringan bervariasi menurut jenis media saringan pasir up flow. Secara keseluruhan ketiga saringan memiliki kemampuan menyaring yang efektif menurunkan kadar Mangan. Penurunan tertinggi terjadi pada saringan $\mathrm{C}$ dengan mendia pasir laut $(99,07 \%)$.

\section{Kesimpulan}

Saringan Pasir Up Flow dimana saringan A dengan media pasir laut, saringan $\mathrm{B}$ dengan media pasir darat dan saringan $\mathrm{C}$ dengan media pasir laut efektif menurunkan kadar kekeruhan dan mangan, sedangkan total coliform untuk dan E.coli masih melebihi baku mutu yg disyaratkan.

\section{Saran}

Perlu dilakukan penelitian lanjutan terhadap pengaruh ketebalan media yang bervariasi dan diameter yang lebih halus agar dapat menurunkan colform dan E.coli secara efektif.

\section{Daftar Pustaka}

1. Chandra, Budiman (2007), Pengantar Kesehatan Lingkungan,

2. Katiho, A.S, Joseph, W.B.S, Malonda, N.S.H, 2011, Gambaran Kondisi Fisik Sumur Galidi Tinjau dari Aspek Kesehatan Lingkungan dan Perilaku Pengguna Sumur Gali di Kelurahan Sumompo Kecamatan Tuminting Kota Manado, Fakultas
Kesehatan Masyarakat, Universitas Samratulangi Manado

3. Kurniawan, R (2015), Permasalahan dan Ketersediaan Air Bersih dan Solusinya. www//http.himatesil.blogspot.com. diakses tanggal 1 April 2016.

4. Mirka Pataras, dkk., (2017), Analisis Penggunaan Pasir Pantai, Darat, Dan Sungai Terhadap Kinerja Laston Dan Lataston Wearing Course, Prosiding Simposium II -UNIID 2017e-ISBN: 978979-587-734-9 Palembang, 19-20 September 2017479

5. Quddus Rachmat, 2014, Teknik Pengolahan Air Bersih dengan Sistem Saringan Pasir Lambat (Downflow) Yang Bersumber Dari Sungai Musi, Jurnal Teknik Sipil dan Lingkungan Vol. 2, No. 4, Desember 2014, Universitas Sriwijaya J1. Palembang-Prabumulih KM. 32 Indralaya,Sumatera Selatan, Korespondensi Penulis : quddusrachmat@gmail.com

6. Suprihatin, Suparno, (2013), Teknologi Proses Pengolahan Air, Penerbit IPB Press, Taman Kencana Bogor.

7. Timpua, Jasman, Pianaung, (2015), Modifikasi Saringan Air Celup untuk Menurunkan Kekeruhan Air Sumur Gali. Karya Tulis Ilmiah tidak dipublikasikan. Jurusan Kesehatan Lingkungan Poltekkes Kemenkes Manado

8. Tombokan, S.N.E, (2014), Uji coba Saringan Air Celup untuk Menurunkan Kekeruhan Air Sumur Gali. Karya Tulis Ilmiah tidak dipublikasikan. Jurusan Kesehatan Lingkungan Poltekkes Kemenkes Manado 